UDC 314.7.044

LBC 60.52

\title{
DYNAMICS OF STUDENTS MIGRATION INTENTIONS AS A RESPONSE TO THE DEVELOPMENT OF VOLGOGRAD AGGLOMERATION
}

\author{
Elena V. Melnikova \\ Volgograd State Technical University, Volgograd, Russian Federation \\ Natalia V. Kazanova \\ Volgograd State Technical University, Volgograd, Russian Federation
}

Andrey V. Shtyrov

Volgograd State Socio-Pedagogical University, Volgograd, Russian Federation

\begin{abstract}
The development of urban agglomerations is one of the leading modern urbanistic trends. In Russia this trend has a number of features: the "pumping" of resources, including human resources, between the agglomerations, and the rapid growth of a few agglomerations due to the degradation of the rest. Among them is the Volgograd agglomeration, which once claimed the role of the industrial, logistic and intellectual center of the South of Russia. In the context of considering this problem, the authors investigated the migration intentions of the most mobile part of the population, the student youth. The authors systematized scientific publications on the topic of research and carried out a comparative analysis of statistics from open sources and official statistics. These data were compared with the results of the monitoring of students opinions carried out by the authors in the period from 2012 to 2019. A total of 1312 people were interviewed. The average age of respondents is $22-24$ years. Analysis of students responses to the questionnaire showed that a significant part of the students would like to leave Volgograd. The volume of such answers in questionnaires grows year by year. Monitoring data revealed trends in the migration intentions of young people. According to the results of the poll, the main reasons for the intention of respondents to leave the Volgograd agglomeration are: the depressed state of the agglomeration economy and dissatisfaction with the quality of life. Comparison of the picture of students migration sentiments with Rosstat data on migration in Volgograd shows that the declared intentions of students coincide with reality. Young people from country areas of the region mainly come to Volgograd, and from the regional center they leave for other regions. The pace of development of the Volgograd agglomeration, low in comparison with other large agglomerations, leaves Volgograd little chance of improving the demographic situation in the coming years. The problem is so acute that it requires specific urgent actions and fundamental changes in the management systems of the city and urban agglomerations. The main goal of these actions should be to equalize the quality of life in the regions while adhering to the principle $\ll$ of diversifying regional development, taking into account the unique economic, cultural, and geographical characteristics of each agglomeration.

Key words: urban agglomeration, migration, demographic situation, the quality of life, students, poll.

Citation. Melnikova E.V., Kazanova N.V., Shtyrov A.V. Dynamics of Students Migration Intentions As a Response to the Development of Volgograd Agglomeration. Logos et Praxis, 2021, vol. 20, no. 3, pp. 130-145. (in Russian). DOI: https://doi.org/10.15688/lp.jvolsu.2021.3.13

УДК 314.7.044

ББК 60.52
\end{abstract}

\section{ДИНАМИКА МИГРАЦИОННЫХ НАСТРОЕНИЙ СТУДЕНТОВ КАК ОТВЕТ НА РАЗВИТИЕ ВОЛГОГРАДСКОЙ АГЛОМЕРАЦИИ}

\author{
Елена Витальевна Мельникова
}

Волгоградский государственный технический университет, г. Волгоград, Российская Федерация 
Наталия Витальевна Казанова

Волгоградский государственный технический университет, г. Волгоград, Российская Федерация

\section{Андрей Вячеславович Штыров}

Волгоградский государственный социально-педагогический университет, г. Волгоград, Российская Федерация

Аннотация. Развитие городских агломераций - один из ведущих современных урбанистических трендов. В России ему присущ ряд особенностей, среди которых отметим «перекачивание» ресурсов, в том числе человеческих, бурный рост одних агломераций за счет других, переживающих деградацию и депопуляцию. К числу последних относится Волгоградская агломерация, некогда претендовавшая на роль промышленного, логистического и интеллектуального центра Юга России. В контексте рассмотрения данной проблемы авторы исследовали миграционные настроения наиболее мобильной части населения - студенческой молодежи. Были систематизированы научные публикации по теме исследования и проведен сравнительный анализ статистических данных из открытых источников и официальной статистики. Эти данные были сопоставлены с результатами проведенного авторами в период с 2012 по 2019 г. мониторинга мнений студентов двух вузов Волгограда (ВолгГТУ и ВГСПУ). Всего было опрошено 1312 человек. Средний возраст опрошенных - 22-24 года. Анализ данных мониторинга показал, что значительная часть респондентов не связывает свое будущее с Волгоградом, и доля таких ответов в анкетах год от года растет. По данным мониторинга, основными причинами задекларированного респондентами намерения покинуть Волгоградскую агломерацию являются депрессивное состояние экономики агломерации и неудовлетворенность качеством жизни. Сопоставление картины миграционных настроений студентов с данными Росстата по миграции в Волгограде показывает совпадение заявленных намерений студентов с реальностью: молодежь из области в основном приезжает в Волгоград, а из областного центра уезжает в другие регионы. Темпы развития Волгоградской агломерации, низкие по сравнению с другими крупными агломерациями, оставляют Волгограду мало шансов на улучшение демографической ситуации в ближайшие годы. Проблема является настолько острой, что требует конкретных экстренных действий и кардинальных изменений в системах управления городом и городскими агломерациями, главной целью которых должно стать выравнивание уровня качества жизни в регионах при одновременном соблюдении принципа диверсификации регионального развития с учетом уникальных экономических, культурных, географических особенностей каждой агломерации.

Ключевые слова: городская агломерация, миграция, демографическая ситуация, качество жизни, студенты, миграционные настроения.

Цитирование. Мельникова Е. В., Казанова Н. В., Штыров А. В. Динамика миграционных настроений студентов как ответ на развитие волгоградской агломерации // Logos et Praxis. -2021. - T. 20, № 3. - C. 130-145. DOI: https://doi.org/10.15688/lp.jvolsu.2021.3.13

\section{Введение}

Формирование городских агломераций является одним из ведущих мировых трендов. В 2009 г. количество людей, живущих в городских районах (3,42 млрд), впервые в истории превысило количество людей, проживающих в сельских районах (3,41 млрд), то есть с данного момента мир стал более городским, чем сельским [Urban and Rural... web]. По данным Всемирного банка, на 2019 г. доля городского населения в мире составляет 55,71\% [Urban population... web].

В странах с активно развивающимися экономиками картина еще более выразительна, чем в целом по миру. Так, в Китае с 1978 по 2009 г. уровень урбанизации вырос с 17,4 \% до 46,6 \%. С 2000 г. города Китая разраста- ются примерно на $10 \%$ ежегодно [Calabro web]. В Индии число людей, живущих в городских районах, выросло на $31,2 \%$ в период с 1991 по 2001 год. Общая численность городского населения в стране по данным переписи 2011 г. составила более 377 млн, что составляет $31,16 \%$ от общей численности населения [Census... web]. В Бразилии, по данным переписей населения, опубликованных Бразильским институтом географии и статистики, в 2000 г. в городах было сконцентрировано 81,19\% населения страны, а в $2010-$ 84,36 \% [Population Census... web].

Существенный вклад в возникновение и развитие феномена городских агломераций внес научно-технический прогресс, который способствовал развитию индустрии и автоматизации производства. Резкий рост численно- 
сти городского населения в 30-е гг. XX в. был обусловлен началом индустриализации и ростом промышленности. Рост агломераций как в мире, так и в России, приходящийся на конец 90-х гг., связан с формированием, становлением и развитием информационного общества. Наличие научных и учебных центров, притягивающих молодое поколение, и в наше время остается одним из основных факторов развития городских агломераций [Карачурина, Мкртчян 2017; Вяльшина, Дакирова 2020; Миронова 2017].

Положение в России, с одной стороны, соответствует общемировой тенденции: около 49 млн человек, или 34 \% населения страны, проживают в 20 крупнейших городских агломерациях [Экономика... web], а общая доля городского населения в России составляет $74,43 \%$. Тенденция снижения доли сельского населения продолжается.

С другой стороны, в развитии городских агломераций в России есть существенная особенность. В результате закрытия промышленных предприятий, трудностей ведения бизнеса и низкой покупательной способности населения среди российских городских агломераций наблюдается неравномерность развития. Только 3 крупнейших агломерации - Московская, Санкт-Петербургская и Екатеринбургская - показывают опережающие показатели по совокупной производительности в сравнении со среднероссийским уровнем, а для агломераций нижней части двадцатки (Омская, Саратовская, Волгоградская) характерны процессы деградации экономики и оттока населения. Условно назовем данные агломерации «депрессивными». Разрыв между самой «богатой» и самой «бедной» по объему валового городского продукта на душу населения (соответственно, Московской и Волгоградской) агломерациями составляет 2,75 раза [Экономика... web].

В депрессивных агломерациях наблюдаются процессы, характерные скорее для малых поселений и моногородов, в частности, отрицательные миграционные потоки: вместо того, чтобы быть точкой притяжения, такая агломерация становится донором мигрантов для более успешных, динамично развивающихся агломераций. В результате складывается ситуация, когда вместо равномерного развития городских агломераций и возникновения новых в России мы наблюдаем картину «перекачивания» ресурсов из одних агломераций в другие, бурного роста немногих агломераций за счет деградации остальных.

Изучение миграционных настроений части волгоградского студенчества, предпринятое в настоящей работе, может оказаться полезным для преодоления негативных тенденций в развитии городских агломераций России.

\section{Обзор литературы}

Формирование городских агломераций вызывает пристальный интерес ученых, особенно в странах с бурно развивающимися городами и городскими агломерациями: США [Рубл 2013; Walker 2015], Испании [Feria Toribio web; Olazabal, Bellet 2018], Китая [Chong, Qin, Ye 2016], Японии [Mori web].

В Индии после переписи 2011 г. был законодательно закреплен термин «городская агломерация», определяющий интегрированный городской район, состоящий из центрального города вместе с его смежными, преимущественно сельскохозяйственными, пригородами [Census... web].

Изучение процесса формирования городских агломераций в России долгое время было затруднено в силу отсутствия строгого определения соответствующего понятия [Лаппо, Полян, Селиванова web]. Так, Н.Р. Ижгузина в 2014 г. собрала и проанализировала 45 различных определений понятия «агломерация» из российских источников [Ижгузина 2014]. В.А. Шабашев с соавторами в 2016 г. указывали: «Не существует общепринятых критериев выделения городских агломераций» [Шабашев (ред.) 2016, 4]. П.В. Терелянский и А.С. Мельников тогда же отмечали, что понятие агломерации «не закреплено законодательно» [Терелянский, Мельников 2016, 62]. Только в 2019 г. в «Стратегии пространственного развития Российской Федерации на период до 2025 года» зафиксированы понятия «крупной агломерации» и «крупнейшей агломерации» [Стратегия... web].

Среди основных критериев городской агломерации исследователи отмечают: наличие крупного города-ядра, к которому примыкают города-спутники [Шабашев (ред.) 2016, 
10]; высокую концентрацию трудовых ресурсов и плотность населения [Lee 2015, 18]; интенсивность, плотность и непрерывность застройки, наличие единой инфраструктуры и транспортной сети; маятниковую миграцию населения между ядром и периферией агломерации [Хуснутдинова, Балина, Развалова 2019]; высокий процент населения, занятого в несельскохозяйственном секторе [Harrison, Heley 2015].

В последние годы исследования развития агломераций в России активизировались. В центре внимания авторов такие вопросы, как функционально-территориальная структура агломераций [Хуснутдинова, Балина, Развалова 2019]; перспективы их развития [Кузнецов, Межевич, Шамахов 2019; Лапин, Вуйко 2019] и препятствующие этому развитию проблемы [Павлов 2019]. Проблеме регионального неравенства в России, которая накладывает свой отпечаток на специфику развития российских агломераций, посвящено исследование Р.Ф. Туровского и К.Ю. Джаватовой [Туровский, Джаватова 2019]. Е.В. Антонов и А.Г. Махрова отмечают, что число развитых агломераций в России остается низким, население имеет тенденцию к концентрации в ядрах крупнейших агломераций, и обращают внимание на начало формирования первой в России надагломерационной структуры - Центрально-Российского мегалополиса, ядром которого является Московская агломерация [Антонов, Махрова 2019]. И.А. Морозова отмечает важность человеческих факторов, обращая особое внимание на трудовые ресурсы, образование, здравоохранение, культуру [Морозова 2005]. В этом свете особо следует отметить исследования миграционных процессов, в том числе интеграции мигрантов, позволяющие выделить их зависимость от экономической ситуации в регионе, наличия и качества учебных заведений, климата и географического положения [Ермакова, Варшавер, Иванова 2020; Пруель, Липатова, Градусова 2020; Бахлов, Кильдюшкина, Липатова 2020].

В контексте нашего исследования наибольший интерес представляют данные о молодежной миграции. Мировые и российские исследования отмечают, что агломерации выступают центрами притяжения для молодежи. Однако в целом по России интенсивная миграция молодых людей характерна для малых городов и сельских поселений [Бадмаева 2018, 160; Мкртчян 2017, 226; Мкртчян 2018]. На формирование устойчивых миграционных трендов основное влияние, по мнению исследователей, оказывают закрытие промышленных предприятий, трудности ведения бизнеса, низкая покупательная способность в большинстве регионов России, а также очень разные темпы развития производства, роста заработной платы и уровня жизни в российских регионах [Бадмаева 2018, 154156; Чернышев 2017, 261; Vasilieva, Danilova, Tokareva 2017]. Л.Б. Карачурина и Н.В. Мкртчян рассматривают возрастной профиль межрегиональной миграции, уделяя значительное внимание феномену молодежной миграции с целью получения высшего образования [Карачурина, Мкртчян 2017]; А.А. Вяльшина и С.Т. Дакирова провели исследование миграционных настроений выпускников сельских школ [Вяльшина, Дакирова 2020]. Миграционные настроения студентов Астрахани исследовала Ю.Г. Миронова [Миронова 2017]. А.Л. Рочева и Е.А. Варшавер изучили зависимость миграционных намерений молодежи от наличия или отсутствия миграционного опыта [Рочева, Варшавер 2020]. Авторы настоящего исследования ранее рассматривали проблемы и особенности развития агломераций Юга России [Мельников, Казанова, Мельникова 2015; Мельников, Мельникова, Казанова 2017].

\section{Материалы и методы}

На основе анализа статистических данных Росстата сделан вывод о возможности рассмотрения миграционной ситуации в Волгоградской городской агломерации как модели миграционных процессов в депрессивных агломерациях России.

Для уточнения миграционных настроений молодежи и выяснения их причин на протяжении 2012-2019 гг. авторы проводили мониторинг миграционных настроений студентов выпускных курсов Волгоградского государственного технического университета (далее - ВолгГТУ) и Волгоградского государственного социально-педагогического университета (далее - ВГСПУ), обучающихся по программе бакалавриата и магистратуры. 
Основной целью мониторинга было выявление динамики миграционных настроений и причин, побуждающих выпускников волгоградских вузов к переезду в другие регионы России и за рубеж.

Задачи мониторинга предполагали: сбор и анализ информации о миграционных настроениях и предпочтениях при выборе будущего места для переезда; приоритет выпускников при оценке места работы и проживания после окончания вуза; мнение о сложившихся тенденциях и темпах экономического развития Волгограда и Волгоградской агломерации; восприятие уровня жизни в Волгограде в сравнении с рядом других городов России.

Мониторинг проводился с 2012 по 2019 г., в ходе количественного исследования было опрошено 1312 человек (табл. 1). Поиск респондентов осуществлялся с помощью метода случайного отбора среди студентов выпускных курсов бакалавриата и магистратуры ВолгГТУ и ИАиС ВолгГТУ ${ }^{1}$, а также ВГСПУ.

Сбор первичной социологической информации проводился в виде опроса в форме раздаточного анкетирования. Средний возраст опрошенных - 22-24 года; $48 \%$ - юноши, $52 \%$ - девушки. $54 \%$ опрошенных студентов до поступления в вуз проживали в Волгограде, $22 \%$ - приезжие из населенных пунктов Волгоградской области, 15 \% приехали из других регионов России. Среди них были представители Астраханской и Ростовской областей, Республики Калмыкия, Республики Дагестан, Республики Северная Осетия - Алания, Кабардино-Балкарской Республики, Чеченской Республики и Ямало-Ненецкого автономного округа. Из стран бывшего Советского Союза было опрошено 5 \% респондентов (Азербайджан, Украина, Таджикистан, Туркмения, Узбекистан). $4 \%$ респондентов приехали в Волгоград из стран дальнего зарубежья: Афганистан, Вьетнам, Гана, Китай, Нигерия, Сирия.

Студентам задавались следующие вопросы: «Где вы планируете жить по окончании вуза?»; «Планируете ли вы работать по спе- циальности после окончания вуза?»; «Что привлекает вас в будущей работе?»; «Какие факторы могут побудить вас уехать из Волгограда на длительный срок?»; «Если вы планируете уехать из Волгограда, то куда именно?»; «Как вы оцениваете условия жизни в Волгограде?»; «Как вы оцениваете тенденции развития Волгограда в последние годы?»; «Есть ли среди Ваших знакомых те, кто уехал или собирается уехать из Волгограда по причине неудовлетворенности качеством жизни?»; «Есть ли среди Ваших знакомых те, кто приехал или собирается приехать в Волгоград на длительный срок, так как их привлекает уровень жизни в городе?»

Мониторинг позволил сравнить миграционные настроения части студентов, постоянно проживающих в Волгограде и приезжих студентов, выяснить причины миграционных настроений и проследить их изменения в период с 2012 по 2019 год.

Результаты мониторинга сопоставлялись с данными Росстата по миграции в Волгоградской области и официальными данными по экономическому развитию Волгограда. Сравнительный анализ позволил увидеть достаточно рельефную картину динамики и причин миграционных настроений волгоградского студенчества. В связи с особенностями формирования статистической отчетности в Российской Федерации, которая группируется по административно-территориальным единицам, мы вынуждены судить о процессах, происходящих в агломерации, на основе анализа процессов, протекающих в городе-ядре, рассматривая его в качестве зеркала развития всей агломерации.

\section{Результаты исследования (основные выводы, полученные по результатам мониторинга)}

В прошлом Волгоградская область имела развитые отрасли машиностроения, нефтедобычи и нефтепереработки, химической про-

Распределение опрошенных по годам

Таблица 1

\section{Р}

\begin{tabular}{|l|c|c|c|c|c|c|c|c|}
\hline Год & 2012 & 2013 & 2014 & 2015 & 2016 & 2017 & 2018 & 2019 \\
\hline $\begin{array}{l}\text { Количество } \\
\text { опрошенных }\end{array}$ & 154 & 161 & 160 & 168 & 170 & 166 & 167 & 166 \\
\hline
\end{tabular}


мышленности и электроэнергетики, свидетельствовавшие о высоком уровне индустриализации. Значительная доля предприятий была сконцентрирована в областном центре, ядре Волгоградской агломерации, в которую кроме собственно Волгограда входят города-спутники Волжский и Краснослободск, а также несколько поселков городского типа. Крупный технологически сложный индустриальный комплекс требовал высококвалифицированных кадров, что привело к возникновению в городеряда высших учебных заведений, также способствующих привлечению в город молодежи.

Однако в период после 1990 г., когда крупные промышленные предприятия, находившиеся в государственной собственности, не смогли адаптироваться к рыночным условиям, статус индустриально развитого региона Волгоградской областью был утерян, и сегодня область стабильно входит в список 10 депрессивных регионов России [Чернышев 2017, 262]. Совокупность сформировавшихся в регионе условий определила неблагоприятные тенденции миграционных потоков: отток из региона людей трудоспособного возраста, обладающих хорошими профессиональными навыками, и приток низкоквалифицированных трудовых мигрантов из стран ближнего зарубежья [Бадмаева 2018, 154; Мкртчян 2018, 78; Vasilieva, Danilova, Tokareva 2017; Мельников, Казанова, Мельникова 2015; Мельников, Мельникова, Казанова 2017; Конина, Мельникова, Мельников 2014; Игнатова, Николенко 2011]. Полагаем, что отмеченная на протяжении нескольких лет динамика миграции снижает качество населения, лишая регион готовности к инновационным преобразованиям. В результате Волгоградская область и соответственно ее центр - Волгоградская городская агломерация - сегодня являются типичными представителями «депрессивных регионов, находящихся в поисках собственной модели роста» [Лапин, Вуйко 2019, 24].

Индекс рынка труда в Волгоградской области в 2014 г. составлял 58,2, в 2015 снизился до 53,2, в 2016 продолжил падение до 52,6. По итогам 2017 г. индекс труда составил 56,2, что обеспечило Волгоградской области 31 место в рейтинге регионов [Рынок труда... web].

Население Волгограда в 2019 г., по оценочным данным Волгоградстата, составило 1011 тыс. человек - это порядка $40 \%$ от численности населения Волгоградской области (общая оценочная численность населения области 2499272 человек, доля городского населения 77,2 \%) [Оценка... web]. Для сравнения, в 2016 г. население Волгограда составляло 1016 тыс. человек, около $40 \%$ от численности населения Волгоградской области, которая насчитывала 2545937 человек при доле городского населения 76,6 \% [Волгоградская область... web].

Таким образом, налицо сокращение населения как всей области, так и областного центра, причем можно предположить, что сокращение это происходит прежде всего именно за счет оттока жителей из Волгограда. Это предположение подтверждается также данными Института демографии Национального исследовательского университета «Высшая школа экономики», согласно которым динамика численности населения Волгограда в период 2012-2018 гг. (табл. 2), то есть за время нашего исследования, представляла собой следующую картину [Города... web].

Кроме Волгограда, из центров крупнейших российских городских агломераций устойчивую отрицательную динамику прироста населения в этот период показала только $\mathrm{Ca}$ мара (население сократилось с 1169 тыс. чел. в 2012 г. до 1163 тыс. чел. в 2018 г.).

Остальные агломерации можно поделить на 2 группы. К первой отнесем агломерации с выраженной тенденцией к положительному приросту населения (от 5 до 18 \% в 2018 г. по отношению к 2012 г.), в порядке убывания выраженности динамики: Краснодар, Красноярск, Санкт-Петербург, Москва, Новосибирск, Казань, Екатеринбург, Воронеж, Челябинск, Пермь [Города... web]. Вторую составляют агломерации, демонстрирующие демографичес-

Таблица 2

Численность населения Волгограда в 2012-2018, тыс. чел.

\begin{tabular}{|l|l|l|l|l|l|l|l|}
\hline Годы & 2012 & 2013 & 2014 & 2015 & 2016 & 2017 & 2018 \\
\hline $\begin{array}{l}\text { Численность на- } \\
\text { селения, тыс. чел. }\end{array}$ & 1019 & 1019 & 1018 & 1017 & 1016 & 1016 & 1014 \\
\hline
\end{tabular}


кую стагнацию (прирост менее 5 \%): Уфа, Ростов-на-Дону, Омск, Саратов, Нижний Новгород. При этом в Омске в 2018 г. наблюдалось сокращение населения по сравнению с 2017 г. (1 172 тыс. чел. против 1 176), а в Нижнем Новгороде с 2015 г. установился устойчивый тренд к сокращению населения (1 259 тыс. чел. в 2018 г. против 1268 в 2015 г.) [Города... web].

Таким образом, можно констатировать, что в Волгограде сложилась довольно тревожная демографическая ситуация, которая в перспективе может привести не только к утрате им статуса города-миллионника, но и к потере его значения как ядра городской агломерации, а соответственно, к ее распаду.

Наибольшую тревогу вызывает усиливающийся на протяжении ряда лет отток из Волгограда молодежи. Мировые и российские исследования отмечают, что агломерации выступают центрами притяжения для молодежи, но Волгоградский регион, судя по всему, является исключением из данного правила.

Сложившаяся ситуация, нетипичная для агломераций, подтверждается данными, полученными нами в результате мониторинга, проводившегося среди студентов ВолгГТУ и ВГСПУ в 2012-2019 годах.

Большинство опрошенных студентов (65 \%) планируют работать по специальности, что говорит об осознанном выборе профессии. При этом $28 \%$ респондентов не уверены в дальнейшем трудоустройстве по специальности, что может свидетельствовать как об их профессиональной неуверенности, так и о дефиците привлекательных мест для трудоустройства в Волгоградской агломерации.

По данным 2012 г. к четвертому курсу обучения только 25,97 \% респондентов заявляли о намерении покинуть регион. В 2019 г. переезд в другой город планировали уже 39,76 \% опрошенных студентов (рис. 1). В приоритетном списке для переезда города: Москва, Краснодар, Ростов-на-Дону, Санкт-Петербург. В 2017 г. к списку городов добавился Калининград по причине его близости к европейским странам.

В 2019 г. по сравнению с 2012 г. выросла с 5,19 \% до 21,69 \% доля студентов, предполагавших уехать из региона, если не будет найдена работа в Волгограде в течение шести месяцев после окончания вуза.

В 2019 г. твердую уверенность в том, что останутся жить и работать в Волгограде, высказали 33,13\% респондентов; в 2012 г. таких ответов было $62,34 \%$ (рис. 1). По общим результатам мониторинга, $18 \%$ студентов, приехавших из малонаселенных городских и сельских поселений, планируют остаться в Волгограде; их доля по годам практически не меняется.

По результатам опроса 2019 г., 14 \% респондентов планировали переезд на постоянное место жительства в другую страну, в

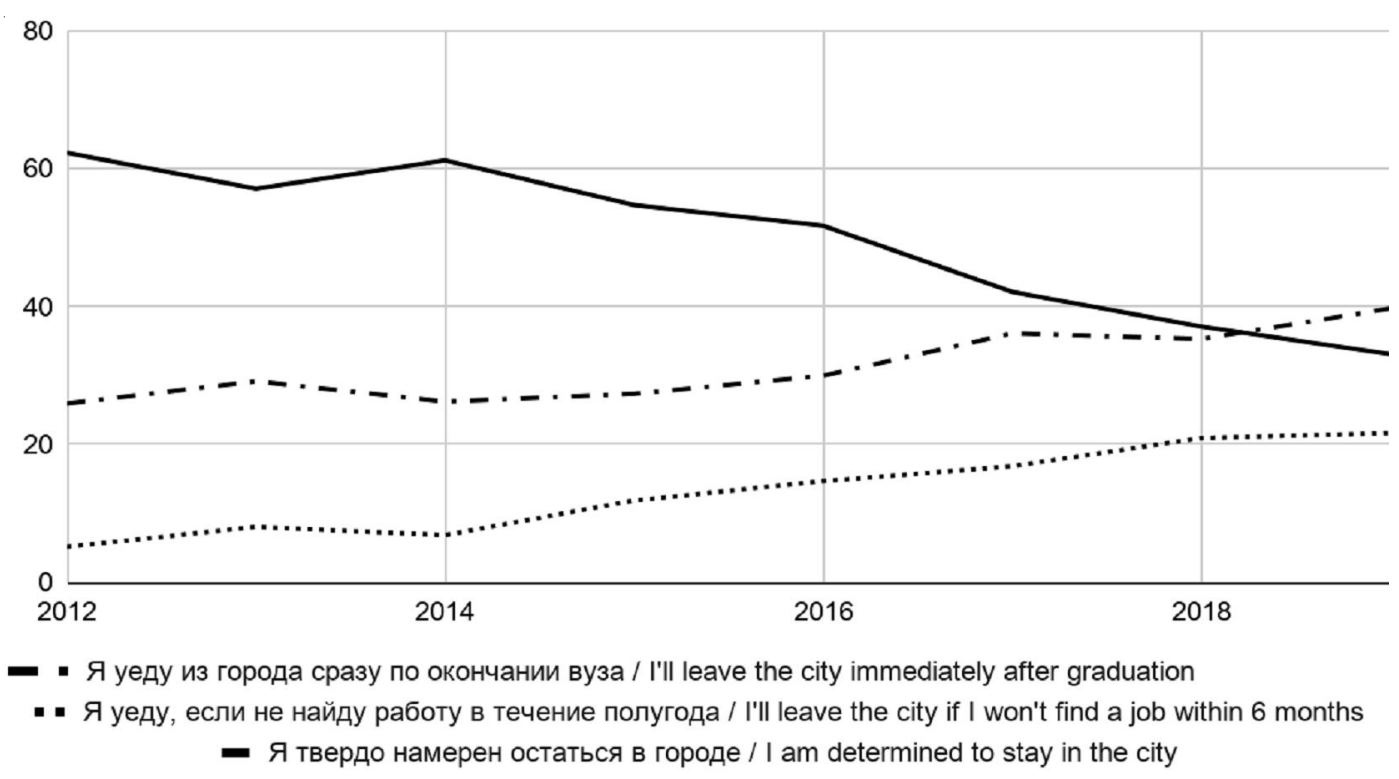

Рис. 1. Миграционные настроения волгоградских студентов (в процентах к числу опрошенных) 
2012 г. таких ответов было зафиксировано 7 \%. Наиболее привлекательными для продолжения обучения и дальнейшего трудоустройства названы Чехия, Англия, США, Канада, Германия (перечислены в порядке убывания частоты в ответах).

Среди студентов-иностранцев (представителей стран дальнего зарубежья), получающих образование в ВолгГТУ и ВГСПУ, подавляющее большинство (96 \%) собираются вернуться на Родину.

Ответы студентов, выходцев из стран бывшего СССР, дают иную картину: $21 \%$ планируют после окончания вуза вернуться на родину, 69 \% собираются остаться в России, но переехать в Москву, Санкт-Петербург, Краснодар, Ростов, и только 10 \% планируют остаться в Волгограде.

В основном студентов побуждает уехать из Волгограда более высокое качество жизни (эту причину называют 40 \% опрошенных) и более высокая заработная плата (24\% опрошенных в среднем за весь период проведения опросов) в других регионах. В 2018-2019 гг. респондентами острее стала ощущаться диспропорция в уровне развития регионов, а основной причиной, побуждающей планировать переезд, респонденты назвали «депрессивное состояние экономики Волгоградской области». Точечные изменения, которые были сделаны к чемпионату мира по футболу (2018 г.), не оказали существенного влияния на уровень развития Волгоградской агломерации.

В 2019 г. 65 \% опрошенных ответили, что «многие знакомые уехали или собираются уехать из города по причине неудовлетворенности качеством жизни», и $54 \%$ - что «нет примеров, когда люди хотели бы приехать в Волгоград».

В течение всего периода мониторинга миграционных настроений 2012-2019 гг. респондентами выражалось недовольство тем, что местная власть реагирует только на распоряжения высшего руководства страны, создавая видимость улучшений, при этом принципиально не меняя положения (68 \% респондентов).

В целом можно отметить, что в 2019 г., по сравнению с результатами опроса 2012 г., негативные настроения среди опрошенных нами представителей студенческой молоде- жи усилились. Респонденты проявляют недовольство местными органами управления, состоянием промышленности, низким уровнем развития инфраструктуры, отсутствием возможностей профессионального развития и форм досуга.

Среди опрошенных студентов, выросших в Волгограде, отмечается тенденция к смене места жительства после окончания вуза. В Волгограде склонны остаться студенты, приехавшие из небольших городских и сельских поселений. По результатам мониторинга можно сделать вывод, что сельские жители едут в Волгоград, а городские жители - в более крупные и развитые регионы России или в другие страны.

Сопоставление картины миграционных настроений студентов ВолгГТУ и ВГСПУ с данными Росстата по миграции в Волгограде показывает совпадение заявленных в ходе мониторинга намерений с реальным трендом.

Так, на протяжении с 2012 по 2019 г. по данным Федеральной службы государственной статистики в Волгограде фиксировалась положительная внутрирегиональная миграция при одновременной отрицательной межрегиональной миграции, причем оба показателя демонстрируют тенденцию к отрицательному росту [Витрина... web] (см. рис. 2).

Еще более выразительную картину наблюдаем при отдельном рассмотрении данных по миграции в возрастных группах 2024 года (условно возраст студентов) и $25-$ 29 лет (выпускники вузов) (см. рис. 3-4) [База данных... web].

Данные Росстата убедительно демонстрируют, что молодежь из области в основном приезжает в Волгоград, а из областного центра, в свою очередь, наблюдается стабильный отток молодежи в другие регионы, что соответствует миграционным настроениям, выявленным нами в ходе опросов студентов.

Заметно, что показатели оттока выше в возрастной группе 25-29 лет, то есть среди молодых специалистов. Показатели межрегиональной миграции молодежи студенческого возраста более «спокойные», хотя резкое увеличение количества покинувших город в 2019 г. настораживает. 


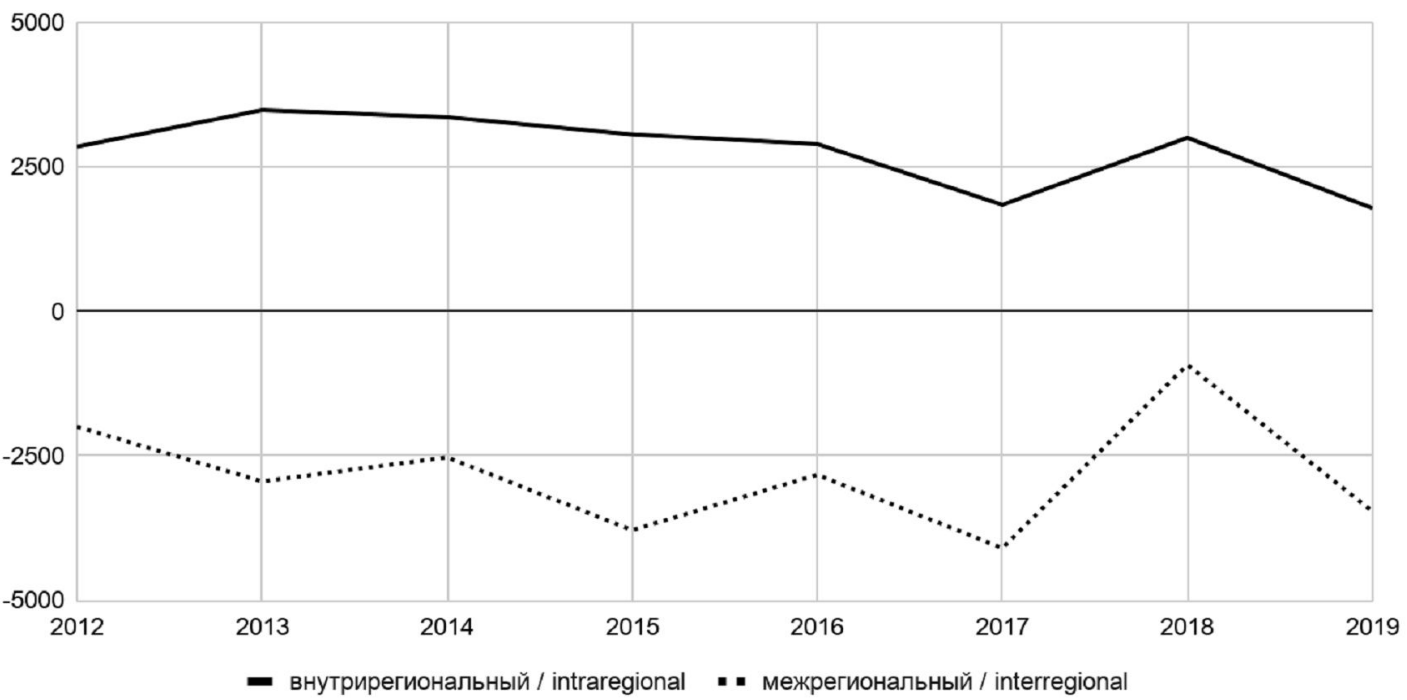

Рис. 2. Миграционный прирост населения в Волгограде в период исследования

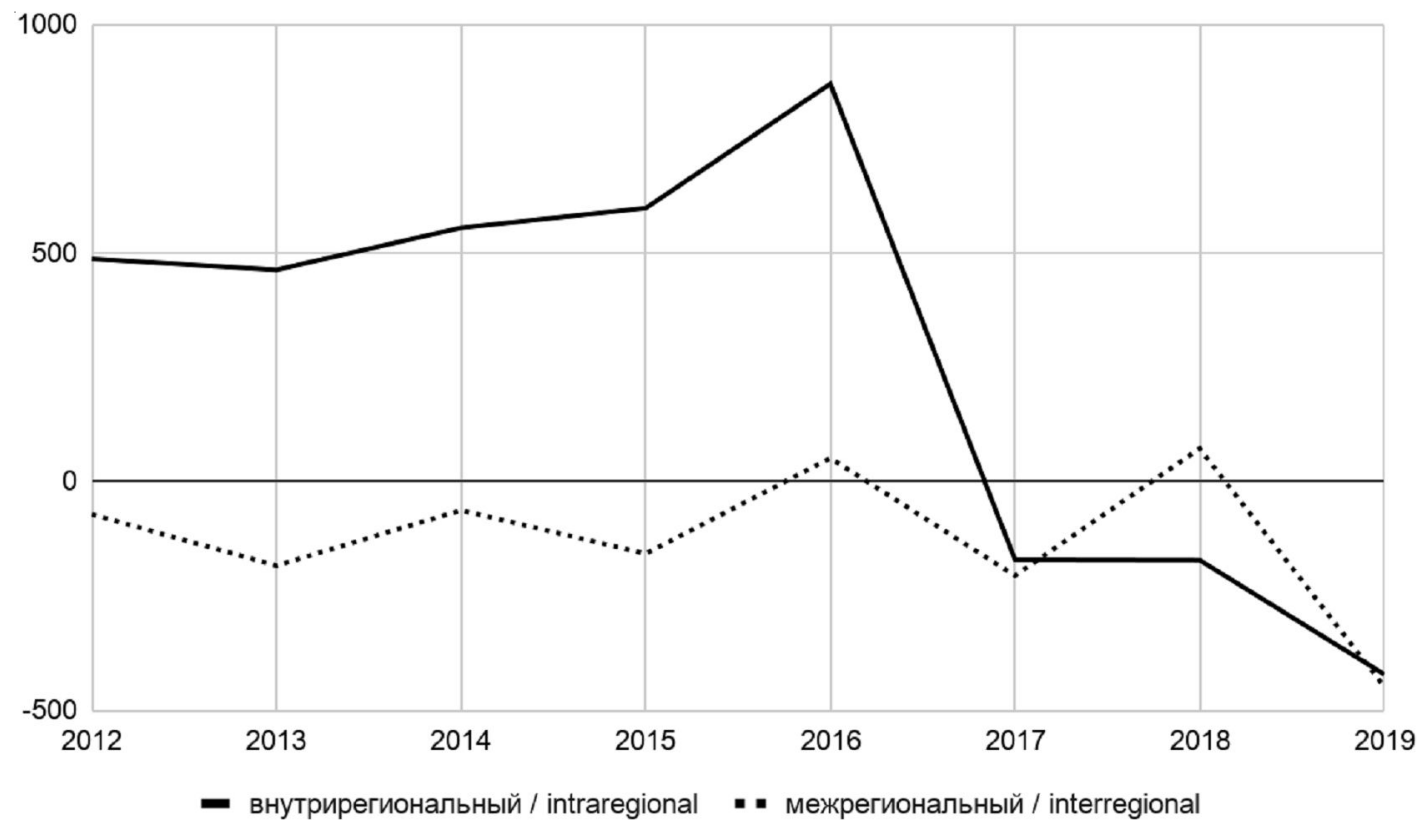

Рис. 3. Миграционный прирост населения в возрасте 20-24 года в Волгограде в период исследования [База данных... web] 


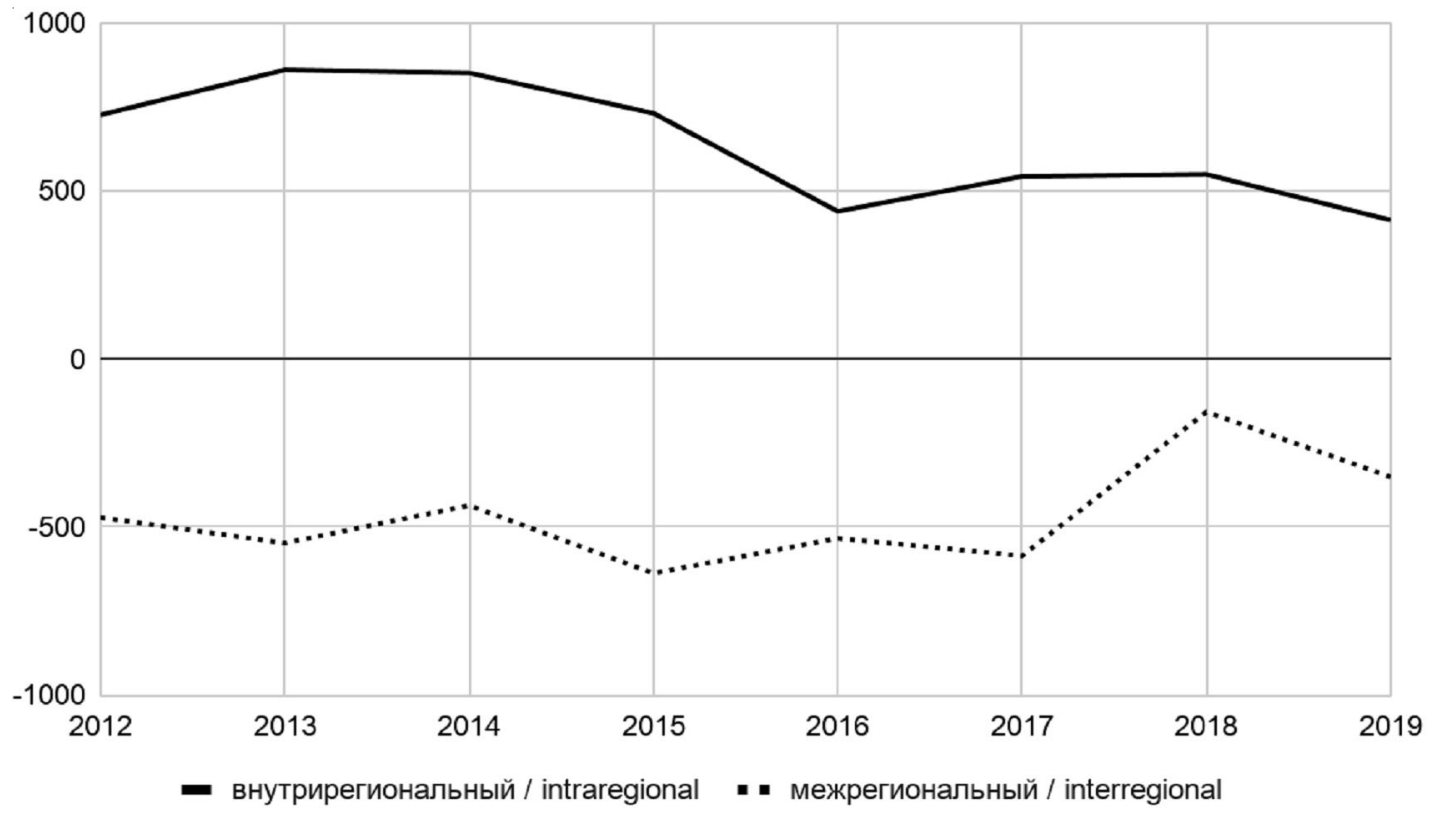

Рис. 4. Миграционный прирост населения в возрасте 25-29 лет в Волгограде в период исследования [База данных... web]

\section{Заключение}

Учитывая, что мониторинг миграционных намерений студентов проводился нами на протяжении восьми лет в двух крупнейших вузах Волгограда, один из которых (ВолгГТУ) является опорным университетом региона, а полученные результаты сопоставлялись с данными Росстата, подтверждающими их, можно сделать вывод, что выявленный негативный тренд в миграционных настроениях характерен для волгоградской молодежи в целом. Среди формирующих его причин особое внимание следует обратить на депрессивное состояние экономики агломерации и неудовлетворенность качеством жизни. Респонденты отмечали: недовольство местными органами управления; низкий уровень развития инфраструктуры; ограниченный набор форм досуга; отсутствие возможностей трудоустройства по специальности и профессионального развития.

Фиксируя низкие по сравнению с крупными агломерациями темпы развития, полагаем, что у Волгоградской агломерации в ближайшие годы мало реальных перспектив к улучшению демографической ситуации. Проблема становится настолько насущной, что требует не только пристального внимания и обсуждения, но и конкретных экстренных дей- ствий и кардинальных изменений в системах управления городом и городскими агломерациями [Павлов 2019].

Локальные мероприятия, направленные на решение обострившихся проблем, отдельные программы и проекты поддержки конкретного региона или муниципалитета, способны обеспечить кратковременное положительное влияние в местах оказания помощи или реализации программ поддержки, однако не могут стать стимулом к эффективному росту. Так как детерминантом региональной мобильности выступает уровень развития экономики, понятно, что регионы-аутсайдеры не смогут конкурировать с лидерами, которые ускоряют темпы и повышают потенциал роста. По-прежнему концентрация общественной, политической и экономической жизни будет сфокусирована в нескольких агломерацияхдоминантах, при этом для большинства агломераций вероятны стагнация и депрессия. Учитывая сформировавшееся недоверие к местной власти, а также усиливающийся запрос среди молодежи на административную открытость, прозрачность бюджетных трат, на социальную справедливость, стоит определить направления развития, которые будут отвечать современным запросам и способствовать росту доверия. Например, перспективной выглядит практика «совместного ве- 
дения бюджета», которую описывает Б. Рубл: местное правительство бразильского города Порту-Алегри с 1989 г. выделило «часть бюджета на строительство и обслуживание и пригласило горожан определить приоритетные направления использования этих средств, выбрать делегатов для разработки совместно с экспертами конкретных предложений по расходам и проголосовать за финансирование получившихся в итоге предложений» [Рубл 2013, 281-282]. Как подчеркивает исследователь, опыт оказался настолько успешным, что сходные программы были запущены не только в других городах Бразилии, но и «растиражированы по всему миру» [Рубл 2013, 282].

Итак, мы полагаем, что главной целью преобразований городских агломераций должно стать выравнивание уровня качества жизни в регионах. Территориальное развитие необходимо выстраивать таким образом, чтобы в каждом регионе или агломерации состояние системы здравоохранения, образования, культуры, транспортной инфраструктуры и возможности трудоустройства соответствовали современным потребностям. При этом необходимо соблюдать принцип диверсификации регионального развития, учитывая уникальные экономические, культурные, географические особенности каждой агломерации.

\section{ПРИМЕЧАНИЕ}

${ }^{1}$ До 2016 г. самостоятельный вуз - Волгоградский государственный архитектурно-строительный университет, с 2016 г. структурное подразделение ВолгГТУ - Институт архитектуры и строительства ВолгГТУ.

\section{СПИСОК ЛИТЕРАТУРЫ}

Антонов, Махрова 2019-Антонов Е.В., Махрова А.Г. Крупнейшие городские агломерации и формы расселения надагломерационного уровня в России // Известия РАН. 2019. № 4. С. $31-$ 45. DOI: https://doi.org/10.31857/S258755662019431-45.

Бадмаева 2018 - Бадмаева Н.В. Миграция сельского населения южнороссийских регионов: проблемы, тенденции, направления // Oriental Studies. 2018. T. 11, № 3. C. 152-164. DOI: 10.22162/2619-0990-2018-37-3-152-164.
База данных... web - База данных показателей муниципальных образований: Волгоградская область [Федеральная служба государственной статистики] // https://rosstat.gov.ru/dbscripts/ munst/munst18/DBInet.cgi.

Бахлов, Кильдюшкина, Липатова 2020 - Бахлов И.В., Кильдюшкина И.Г., Липатова Л.Н. Интеграция и социальная адаптация мигрантов: основы государственной политики и опыт Республики Мордовия // Ойкумена. Регионоведческие исследования. 2020. № 1. С. 66-78. DOI: https://doi.org/10.24866/1998-6785/2020-1/66-78.

Витрина... web - Витрина статистических данных: Миграционный прирост населения по городам с числом жителей 100 тыс. человек и более (Волгоград) [Федеральная служба государственной статистики] // https://showdata. gks.ru/report/279006/?\&filter_1_0=2012-01$01+00 \% 3 \mathrm{~A} 00 \% 3 \mathrm{~A} 00 \% 7 \mathrm{C}-52 \% 2 \mathrm{C} 2013-01-$ $01+00 \% 3 \mathrm{~A} 00 \% 3 \mathrm{~A} 00 \% 7 \mathrm{C}-52 \% 2 \mathrm{C} 2014-01-$ $01+00 \% 3 \mathrm{~A} 00 \% 3 \mathrm{~A} 00 \% 7 \mathrm{C}-52 \% 2 \mathrm{C} 2015-01-$ $01+00 \% 3 \mathrm{~A} 00 \% 3 \mathrm{~A} 00 \% 7 \mathrm{C}-52 \% 2 \mathrm{C} 2016-01-$ $01+00 \% 3 \mathrm{~A} 00 \% 3 \mathrm{~A} 00 \% 7 \mathrm{C}-52 \% 2 \mathrm{C} 2017-01-$ $01+00 \% 3 \mathrm{~A} 00 \% 3 \mathrm{~A} 00 \% 7 \mathrm{C}-52 \% 2 \mathrm{C} 2018-01-$ $01+00 \% 3 \mathrm{~A} 00 \% 3 \mathrm{~A} 00 \% 7 \mathrm{C}-52 \% 2 \mathrm{C} 2019-01-$ $01+00 \% 3 \mathrm{~A} 00 \% 3 \mathrm{~A} 00 \% 7 \mathrm{C}-52 \&$ filter 2 - $0=$ 131204\%2C131200\&filter_3_0=109103\&rp_ submit $=\mathrm{t}$.

Волгоградская область... web - Волгоградская область. Население // http://www.volgograd.ru/ volgogradskaya-oblast/naselenie.php.

Вяльшина, Дакирова 2020 - Вяльшина А.А., Дакирова C.T. Социологический анализ миграционных настроений выпускников сельских школ // Регионология. 2020. Т. 28, № 1. С. 159 183. DOI: https://doi.org/10.15507/2413-1407. 110.028.202001.159-183.

Города... web - Города в Российской Федерации с численностью населения 100 тысяч человек и более (тысяч человек, в порядке убывания численности населения) // http://www.demoscope. ru/weekly/ssp/rus_urban100.php.

Ермакова, Варшавер, Иванова 2020 - Ермакова М.А., Варшавер Е.А., Иванова Н.С. Характеристики проживания и интеграция мигрантов в Москве и Московской области // Вестник РУДН. Серия: Социология. 2020. Т. 20, № 2. C. 363-381. DOI: https://doi.org/10.22363/23132272-2020-20-2-363-381.

Игнатова, Николенко 2011 - Игнатова Ю.Е., Николенко Н.А. Влияние региональных условий на адаптационные процессы трудовых мигрантов (на примере Волгоградской области) // Вестник Волгоградского государственного университета. Серия 7, Философия. Социология и социальные технологии. 2011. № 3 (15). С. 43-48. 
Ижгузина 2014 - Ижгузина Н.Р. Концептуальные аспекты понятия «городская агломерация»: актуальные тенденции // Перспективы науки. 2014. № 6 (57). C. 25-34.

Карачурина, Мкртчян 2017 - Карачурина Л.Б., Мкртчян Н.В. Возрастные особенности межрегиональной миграции населения в России // Регион: экономика и социология. 2017. № 4 (96). C. 101-125. DOI: 10.15372/REG20170405.

Конина, Мельникова, Мельников 2014 - Конина О.B., Мельникова Е.В., Мельников А.С. Роль миграционных процессов в формировании региональной конкурентоспособности // Известия Волгоградского государственного технического университета. Серия: Проблемы социально-гуманитарного знания. 2014. Т. 18, № 16 (143). С. 82-85.

Кузнецов, Межевич, Шамахов 2019 - Кузнециов С.В., Межевич Н.М., Шамахов В.А. Стратегия пространственного развития Российской Федерации и перспективы развития приморских агломераций // Управленческое консультирование. 2019. № 6 (126). С. 10-18.

Лапин, Вуйко 2019 - Лапин А.Е., Вуйко М.Б. Модели регионального развития в Российской Федерации и инвестиционные стратегии // Регионология. 2019. Т. 27, № 1. С. 10-29. DOI: https://doi.org/ 10.15507/2413-1407.106.027.201901.010-029.

Лаппо, Полян, Селиванова web - Лаппо Г.М., Полян П.М., Селиванова Т.И. Городские агломерации России [Демоскоп Weekly. 2010. № 407408] // http://www.demoscope.ru/weekly/2010/ 0407/tema01.php.

Мельников, Казанова, Мельникова 2015 - Мельников А.С., Казанова Н.В., Мельникова Е.В. Миграционные процессы как проблема устойчивого развития агломерации // Известия Волгоградского государственного технического университета. Серия: Проблемы социально-гуманитарного знания. 2015. Т. 22, № 8(171). C. 38-41.

Мельников, Мельникова, Казанова 2017 - Мельников А.С., Мельникова Е.В., Казанова Н.В. Проблемы развития современных агломераций на юге России // Социология города. 2017. № 4. C. 41-46.

Миронова 2017 - Миронова Ю.Г. Миграционные установки современной молодежи: региональный аспект // Социология города. 2017. № 4. С. 58-63.

Мкртчян 2017 - Мкртчян Н.В. Миграция молодежи из малых городов России // Мониторинг общественного мнения: Экономические и социальные перемены. 2017. № 1. C. 225-242. DOI: https://doi.org/10.14515/monitoring.2017.1.15.

Мкртчян 2018 - Мкртчян Н.В. Возрастной профиль внутрироссийской трудовой миграции и иных форм пространственной мобильности населения // Региональные исследования. 2018. № 1 (59). C. 72-81.

Морозова 2005 - Морозова И.А. Проблемы управления социально-экономическими процессами (человеческим развитием) региона // $\mathrm{Pe}$ гионология. 2005. № 2 (51). С. 27-35.

Оценка... web - Оценка численности постоянного населения Волгоградской области на 1 января 2020 года и среднем за 2019 год: Территориальный орган Федеральной службы государственной статистики по Волгоградской области // https://volgastat.gks.ru/storage/ mediabank/wEosM7Zb/population_2020.pdf.

Павлов 2019 - Павлов Ю.В. Развитие городских агломераций: проблемы и решения // Среднерусский вестник общественных наук. 2019. T. 14, № 5. C. 112-140.

Пруель, Липатова, Градусова 2020 - Пруель Н.А., Липатова Л.Н., Градусова В.Н. Миграция в современной России: масштабы, основные направления и проблемы // Регионология. 2020. T. 28, № 1. C. 133-158. DOI: https://doi.org/ 10.15507/2413-1407.110.028.202001.133-158.

Рочева, Варшавер 2020 - Рочева А.Л., Вариавер Е.А. Миграционные намерения молодежи с миграционным бэкграундом и без: российский случай // Мониторинг общественного мнения: экономические и социальные перемены. 2020. №3. С. 295-334. DOI: https://doi. org/10.14515/monitoring.2020.3.1632.

Рубл 2013 - Рубл Б. Мировой опыт в эпоху городских агломераций. Уроки для управления Москвой / / Логос. 2013. № 4 (94). С. 267-287.

Рынок труда... web - Рынок труда в регионах Россиииндекс 2018 // http://riarating.ru/infografika/ 20180911/630104345.html.

Стратегия... web - Стратегия пространственного развития Российской Федерации на период до 2025 года: Утверждена распоряжением Правительства Российской Федерации от 13 февраля 2019 г. № 207-p // http://static.government. $\mathrm{ru} / \mathrm{media} /$ files/UVAlqUtT08o60RktoOX122Jj Ae7irNxc.pdf.

Терелянский, Мельников 2016 - Терелянский П.В., Мельников А.C. Факторы, определяющие инновационное развитие городской агломерации // Актуальные проблемы экономики и менеджмента. 2016. № 4 (12). С. 62-67.

Туровский, Джаватова 2019 - Туровский Р.Ф., Джаватова К.Ю. Региональное неравенство в россии: Может ли централизация быть лекарством? // Политическая наука. 2019. № 2. C. 48-73. DOI: https://doi.org/10.31249/poln/2019.02.03.

Хуснутдинова, Балина, Развалова 2019-Хуснутдинова С.Р., Балина Т.А., Развалова А.А. Изме- 
нения функционально-территориальной структуры городской агломерации на рубеже XX-XXI веков (на примере Казанской агломерации) // Вестник Пермского национального исследовательского политехнического университета. Прикладная экология. Урбанистика. 2019. № 3 (35). С. 68-78. DOI: 10.15593/ 2409-5125/2019.03.05.

Чернышев 2017 - Чернышев К.А. Исследование постоянной миграции населения депрессивных регионов России // Экономические и социальные перемены: факты, тенденции, прогноз. 2017. Т. 10, № 4. С. 259-273. DOI: https:// doi.org/10.15838/esc.2017.4.52.15.

Шабашев (ред.) 2016 - Шабашев В.А. (ред.). Городская агломерация: состояние, проблемы, пути развития (на примере Кемеровской области). Кемерово: Кузбассвузиздат, 2016.

Экономика... web - Экономика Российских городов и городских агломераций // http://www. urbaneconomics.ru/sites/default/files/ekonomika rossiyskih_gorodov_i_gorodskih_aglomeraciy_ vypusk_1_iyul_2017.pdf.

Calabro web-Calabro J. Chinese Urbanization: Efforts to Manage the Rapid Growth of Cities [Global Majority E-Journal. 2012. Vol. 3, № 2. P. 75-85] // https:/www.american.edu/cas/economics/ ejournal/upload/calabro_accessible.pdf.

Census... web - Census of India 2011 Urban Agglomerations and Cities // http://censusindia. gov.in/2011-prov-results/paper2/data_files/ India2/1.\%20Data\%20Highlight.pdf.

Chong, Qin, Ye 2016 - Chong Z., Qin C., Ye X. Environmental Regulation, Economic Network and Sustainable Growth of Urban Agglomerations in China // Sustainability. 2016. Vol. 8, № 5. P. 1-21. DOI: https://doi.org/10.3390/ su8050467.

Feria Toribio web - Feria Toribio J. Nuevas periferias urbanas y planificación pública // [La ciudad. Tamaño y crecimiento: ponencias, comunicaciones y conclusiones del III Coloquio de Geografía Urbana. Málaga, Departamento de Geografía de la Universidad, 1999. P. 309-316] // http://www.cervantesvirtual.com/obra-visor/ nuevas-periferias-urbanas-y-planificacin-pblica0/html/0040e3a2-82b2-11df-acc7-002185ce6064 2.html\#I_0_.

Harrison, Heley 2015 - Harrison J., Heley J. Governing Beyond the Metropolis: Placing the Rural in CityRegion Development // Urban Studies. 2015. Vol. 52, № 6. P. 1113-1133. DOI: https://doi.org/ 10.1177/0042098014532853.

Lee 2015 - Lee C.-I. Agglomeration, Search Frictions and Growth of Cities in Developing Economies // Annals of Regional Science. 2015. Vol. 55.
P. 421-451. DOI: https://doi.org/10.1007/s00168015-0708-7.

Mori web-Mori T. Monocentric Versus Polycentric Models in Urban Economics [KIER Discussion Papers Series. 2006. № 611. P. 1-6] // https://www.researchgate.net/publication/ 5161657_Monocentric_Versus_Polycentric_Models in_Urban_Economics.

Olazabal, Bellet 2018 - Olazabal E., Bellet C. Procesos de urbanización y artificialización del suelo en las aglomeraciones urbanas españolas (19872011) // Cuadernos Geográficos. 2018. Vol. 57, № 2. P. 189-210. DOI: https://doi.org/10.30827/ cuadgeo.v57i2.5920.

Population Census... web - Population Census IBGE (Instituto Brasileiro de Geografia e Estatística): // https://www.ibge.gov.br/en/statistics/social/ population/18521-2000-population-census. html?edicao $=18523 \& \mathrm{t}=$ downloads.

Urban and Rural... web - Urban and Rural Areas 2009 // https://www.un.org/en/development/desa/ population/publications/urbanization/urbanrural.asp.

Urban population... web - Urban Population (\% of Total Population) // https://data.worldbank.org/ indicator/SP.URB.TOTL.IN.ZS.

Vasilieva, Danilova, Tokareva 2017 - Vasilieva E., Danilova E., Tokareva S. Migration Attractiveness Of The Social And Economic Spaces: Volgograd Case Study// Theoretical and Empirical Researches in Urban Management. 2017. Vol. 12, № 1. P. 5-20.

Walker 2015 - Walker R. Building a Better Theory of the Urban: A Response to "Towards a New Epistemology of the Urban?" // City. 2015. Vol. 19, № 2-3. P. 183-191. DOI: https://doi.org/10.1080/ 13604813.2015.1024073.

\section{REFERENCES}

Antonov E.V., Makhrova A.G., 2019. Largest Urban Agglomerations and Super-Agglomerations in Russia. Izvestiya RAN, no. 4, pp. 31-45. DOI: https://doi.org/10.31857/S2587-55662019431-45.

Badmaeva N., 2018. Migration of Rural Population in Southern Russian Regions: Problems, Trends, Directions. Oriental Studies, vol. 11, no. 3, pp. 152-164. DOI: https://doi.org/10.22162/26190990-2018-37-3-152-164.

Database of Municipalities: Volgograd Region. Federal State Statistics Service. URL: https://rosstat. gov.ru/dbscripts/munst/munst18/DBInet.cgi.

Bakhlov I.V., Kildiyshkina I.G., Lipatova L.N., 2020. Integration and Social Adaptation of Migrants: The Basics of Public Policy and the Experience 
of the Republic of Mordovia. Ojkumena. Regional Researches, no. 1, pp. 66-78. DOI: https://doi.org/10.24866/1998-6785/2020-1/66-78.

Showcase of Sstatistical Data: Migration Population Growth in Cities with a Population of 100 Thousand People or More (Volgograd). Federal State Statistics Service. URL: https://showdata. gks.ru/report/279006/?\&filter_1_0=2012-01$01+00 \% 3 \mathrm{~A} 00 \% 3 \mathrm{~A} 00 \% 7 \mathrm{C}-52 \% 2 \mathrm{C} 2013-01-$ $01+00 \% 3 \mathrm{~A} 00 \% 3 \mathrm{~A} 00 \% 7 \mathrm{C}-52 \% 2 \mathrm{C} 2014-01-$ $01+00 \% 3 \mathrm{~A} 00 \% 3 \mathrm{~A} 00 \% 7 \mathrm{C}-52 \% 2 \mathrm{C} 2015-01-$ $01+00 \% 3 \mathrm{~A} 00 \% 3 \mathrm{~A} 00 \% 7 \mathrm{C}-52 \% 2 \mathrm{C} 2016-01-$ $01+00 \% 3 \mathrm{~A} 00 \% 3 \mathrm{~A} 00 \% 7 \mathrm{C}-52 \% 2 \mathrm{C} 2017-01-$ $01+00 \% 3 \mathrm{~A} 00 \% 3 \mathrm{~A} 00 \% 7 \mathrm{C}-52 \% 2 \mathrm{C} 2018-01-$ $01+00 \% 3 \mathrm{~A} 00 \% 3 \mathrm{~A} 00 \% 7 \mathrm{C}-52 \% 2 \mathrm{C} 2019-01-$ $01+00 \% 3 \mathrm{~A} 00 \% 3 \mathrm{~A} 00 \% 7 \mathrm{C}-52 \&$ filter $20=$ 131204\%2C131200\&filter_3_0=109103\&rp_ submit $=$.

Volgograd region. Population. URL: http:// www.volgograd.ru/volgogradskaya-oblast/ naselenie.php.

Vyalshina A.A., Dakirova S.T., 2020. Sociological Analysis of Migration Attitudes of Rural School Graduates. Regionologiya, vol. 28, no. 1, pp. 159183. DOI: https://doi.org/10.15507/24131407.110.028.202001.159-183.

Cities in the Russian Federation with a Population of 100 Thousand People or More (Thousands of People, in Descending Order of Population). URL: http://www.demoscope.ru/weekly/ssp/ rus_urban100.php.

Ermakova M.A., Varshaver E.A., Ivanova N.S., 2020. Features of Settlement and Integration of Migrants in Moscow and the Moscow Region. Vestnik RUDN. Seriya: Sociology, vol. 20, no. 2, pp. 363-381. DOI: https://doi.org/10.22363/23132272-2020-20-2-363-381.

Ignatova Yu.E., Nikolenko N.A., 2011. Influence of Regional Conditions on Adaptable Processes of Labor Migrants (Case Study of the Volgograd Region). Vestnik Volgogradskogo gosudarstvennogo universiteta. Seriya 7: Filosofiya. Sociologiya $i$ social'nye tekhnologii, no. 3 (15), pp. 43-48.

Izhguzina N.R., 2014 Conceptual Aspects of the Term "Urban Agglomeration": Current Trends. Perspektivy nauki, no. 6(57), pp. 25-34.

Karachurina L.B., Mkrtchyan N.V., 2017. Age Specific of Interregional Migration in Russia. Region: economika i sociologiya, no. 4 (96), pp. 101-125. DOI: https://doi.org/10.15372/ REG20170405.

Konina O.V., Melnikova E.V., MelnikovA.S., 2014. Role of Migration Processes in the Formation of Regional Competitiveness. Izvestiya Volgogradskogo gosudarstvennogo tekhnicheskogo universiteta.
Seriya: Problemy social'no-gumanitarnogo znaniya, vol. 18, no. 16 (143), pp. 82-85.

Kuznetsov S.V., Mezhevich N.M., Shamakhov V.A., 2019. Strategy of Spatial Development of the Russian Federation and Prospect of Seaside Agglomerations Development. Upravlencheskoe konsul'tirovanie, no. 6 (126), pp. 10-18. DOI: https://doi.org/10.22394/1726-1139-2019-6-10-18.

Lapin A.E., Vuiko M.B., 2019. Models of Regional Development in the Russian Federation and Investment Strategies. Regionologiya, vol. 27, no. 1, pp. 10-29. DOI: https://doi.org/10.15507/ 2413-1407.106.027.201901.010-029.

Lappo G.M., Polyan P.M., Selivanova T.I., 2010. Urban agglomerations of Russia. Demoskop Weekly, no. 407-408. URL: http://www.demoscope.ru/ weekly/2010/0407/tema01.php.

Melnikov A.S., Kazanova N.V., Melnikova E.V., 2015. Migration Processes as a Problem of Sustainable Development of Agglomeration. Izvestiya Volgogradskogo gosudarstvennogo tekhnicheskogo universiteta. Seriya: Problemy social'no-gumanitarnogo znaniya, vol. 22, no. 8 (171), pp. 38-41.

Melnikov A.S., Melnikova E.V., Kazanova N.V., 2017. Problems of the Development of Contemporary Agglomerations in the South of Russia. Sociologiya goroda, no. 4, pp. 41-46.

Mironova Yu.G., 2017. Migration Directives of the Modern Youth: Regional Aspect. Sociologiya goroda, no. 4, pp. 58-63.

Mkrtchan N.V., 2017. The Youth Migration From Small Towns in Russia. Monitoring obshchestvennogo mneniya: Ekonomicheskie $i$ social'nye peremeny, no. 1, pp. 225-242. DOI: https://doi.org/ 10.14515/monitoring.2017.1.15.

Mkrtchyan N.V., 2018. Age Profile of Russian Internal Labor Migration and Other Forms of Spatial Population Mobility. Regional'nye issledovaniya, no. 1(59), pp. 72-81.

Morozova I.A., 2005. Problems in Managing Social and Economic Processes (Personality Development) in the Region. Regionologiya, no. 2 (51), pp. 27-35.

Estimate of the Permanent Population of the Volgograd Region as of January 1, 2020 and the Average for 2019: Territorial Office of the Federal State Statistics Service for the Volgograd Region. URL: https://volgastat.gks.ru/storage/mediabank/ wEosM7Zb/population_2020.pdf.

Pavlov Y.V., 2019. Development of Urban Agglomerations: Problems and Solutions. Srednerusskij vestnik obshchestvennyh nauk, vol. 14, no. 5, pp. 112-140. DOI: https://doi.org/ 10.22394/2071-2367-2019-14-5-112-140.

Pruel N.A., Lipatova L.N., Gradusova V.N., 2020. Migration in Modern Russia: Scope, Main 
Directions and Problems. Regionologiya, vol. 28, no. 1, pp. 133-158. DOI: https://doi.org/10.15507/ 2413-1407.110.028.202001.133-158.

Rocheva A.L., Varshaver E.A., 2020. Migration Intentions of Youth with and without Migrant Backgrounds: A Russian Case. Monitoring obshchestvennogo mneniya: ekonomicheskie i social'nye peremeny, no. 3, pp. 295-334. DOI: https://doi.org/10.14515/monitoring.2020.3.1632.

Ruble B., 2013. Lessons from Around the World for Moscow Governance in a Global Metropolitan Age. Logos, no. 4 (94), pp. 267-287. URL: https:// gtmarket.ru/library/articles/6609.

Labor Market in the Regions of Russia - Index 2018. URL: https://riarating.ru/infografika/20180911/ 630104345.html.

Spatial Development Strategy of the Russian Federation for the Period up to 2025: Approved by Order of the Government of the Russian Federation No. 207-r Dated February 13, 2019. URL: http://static.government.ru/media/files/ UVAlqUtT08o60RktoOX122JjAe7irNxc.pdf.

Terelyansky P.V., Melnikov A.S., 2016. Factors Determining Innovative Development of Urban Agglomerations. Actual'nye problemy ekonomiki i menedzhmenta, no. 4 (12), pp. 62-67.

Turovsky R.F., Dzhavatova K.Yu., 2019. Regional Disparity in Russia: Can Centralization Become a Remedy? Politicheskaya nauka, no. 2, pp. 4873. DOI: https://doi.org/10.31249/poln/2019.02.03.

Khusnutdinova S.R., Balina T.A., Razvalova A.A., 2019. Changes in the Functional-Territorial Structure of Urban Agglomeration at the Turn of the XXI Century (by the Example of Kazan Agglomeration). Vestnik Permskogo nacional'nogo issledovatel 'skogo politekhnicheskogo universiteta. Prikladnaya ekologiya. Urbanistika, no. 3 (35), pp. 68-78. DOI: 10.15593/2409-5125/2019.03.05.

Chernyshev K.A., 2017. The Study of Permanent Migration of Economically Depressed Regions. Ekonomicheskie i social'nye peremeny: fakty, tendencii, prognoz, vol. 10, no. 4, pp. 259-273. DOI: https://doi.org/10.15838/esc.2017.4.52.15.

Shabashev V.A. (ed.), 2016. Urban Agglomeration: State, Problems, Development Ppaths (by the Example of the Kemerovo Region). Kemerovo, Kuzbassvuzizdat Publ.

Economy of Russian Cities and Urban Agglomerations. URL: http://www.urbaneconomics.ru/sites/ default/files/ekonomika rossiyskih_gorodov i gorodskih_aglomeraciy_vypusk_1_iyul_2017.pdf.

Calabro J., 2012. Chinese Urbanization: Efforts to Manage the Rapid Growth of Cities. Global Majority E-Journal, vol. 3, no. 2, pp. 75-85. URL: https://www.american.edu/cas/economics/ ejournal/upload/calabro_accessible.pdf.
Census of India 2011 Urban Agglomerations and Cities. URL: bhttp://censusindia.gov.in/2011prov-results/paper $2 /$ data_files/India $2 / 1$. \%20Data\%20Highlight.pdf.

Chong Z., Qin C., Ye X., 2016. Environmental Regulation, Economic Network and Sustainable Growth of Urban Agglomerations in China. Sustainability, vol. 8, no. 5, pp. 1-21. DOI: https:// doi.org/10.3390/su8050467.

Feria Toribio J., 1999. New Urban Peripheries and Public Planning. The City. Size And Growth: Presentations, Communications and Conclusions of the III Colloquium of Urban Geography. Málaga, Departamento de Geografía de la Universidad, pp. 309-316.

Harrison J., Heley J., 2015. Governing Beyond the Metropolis: Placing the Rural in City-Region Development. Urban Studies, vol. 52, no. 6, pp. 1113-1133. DOI: https://doi.org/10.1177/ 0042098014532853.

Lee C.-I., 2015. Agglomeration, Search Frictions and Growth of Cities in Developing Economies. Annals of Regional Science, vol. 55, pp. 421451. DOI: https://doi.org/10.1007/s00168-0150708-7.

Mori T., 2006. Monocentric Versus Polycentric Models in Urban Economics. KIER Discussion Papers Series, no. 611, pp. 1-6. URL: https://www. researchgate.net/publication/5161657 Monocentric_Versus_Polycentric_Models_in Urban_Economics.

Olazabal E., Bellet C., 2018. Urbanisation Processes and Land Artificialisation in Spanish Urban Agglomerations (1987-2011). Geographical Notebooks, vol. 57, no. 2, pp. 189-210. DOI: http:// dx.doi.org/10.30827/cuadgeo.v57i2.5920.

Population Census web IBGE (Instituto Brasileiro de Geografia e Estatílística): URL: https:// www.ibge.gov.br/en/statistics/social/ population/18521-2000-population-census. html?edicao $=18523 \& \mathrm{t}=$ downloads.

Urban and Rural Areas 2009. URL: https:// www.un.org/en/development/desa/population/ publications/urbanization/urban-rural.asp.

Urban population (\% of Total Population). URL: https://data.worldbank.org/indicator/SP.URB. TOTL.IN.ZS.

Vasilieva E., Danilova E., Tokareva S., 2017. Migration Attractiveness of the Social and Economic Spaces: Volgograd Case Study. Theoretical and Empirical Researches in Urban Management, vol. 12, no. 1, pp. 5-20.

Walker R., 2015. Building a Better Theory of the Urban: A Response to "Towards a New Epistemology of the Urban?" City, vol. 19, no. 2-3, pp. 183-191. DOI: https://doi.org/10.1080/13604813.2015.1024073. 
Е.В. Мельникова, Н.В. Казанова, А.В. Штыров. Динамика миграционных настроений студентов

\section{Information About the Authors}

Elena V. Melnikova, Candidate of Sciences (Sociology), Associate Professor, Department of Economics and Management, Volgograd State Technical University, Prosp. Lenina, 28, 400005 Volgograd, Russian Federation, evm.34@yandex.ru, https://orcid.org/0000-0002-8914-2181

Natalia V. Kazanova, Candidate of Sciences (Philosophy), Associate Professor, Department of Philosophy and Law, Volgograd State Technical University, Prosp. Lenina, 28, 400005 Volgograd, Russian Federation, nvkazanova@gmail.com, https://orcid.org/0000-0002-4306-7593

Andrey V. Shtyrov, Candidate of Sciences (Pedagogy), Associate Professor, Department of Methods of Teaching Mathematics and Physics, and IT, Volgograd State Socio-Pedagogical University, Prosp. Lenina, 27, 400066 Volgograd, Russian Federation, an.shtyrov@gmail.com, https://orcid.org/0000-0002-9090-7516

\section{Информация об авторах}

Елена Витальевна Мельникова, кандидат социологических наук, доцент, кафедра экономики и управления, Волгоградский государственный технический университет, просп. Ленина, 28, 400005 г. Волгоград, Российская Федерация, evm.34@yandex.ru, https://orcid.org/0000-0002-8914-2181

Наталия Витальевна Казанова, кандидат философских наук, доцент, кафедра философии и права, Волгоградский государственный технический университет, просп. Ленина, 28, 400005 г. Волгоград, Российская Федерация, nvkazanova@gmail.com, https://orcid.org/0000-0002-4306-7593

Андрей Вячеславович Штыров, кандидат педагогических наук, доцент кафедры методики преподавания математики и физики, ИКТ, Волгоградский государственный социальнопедагогический университет, просп. Ленина, 27, 400066 г. Волгоград, Российская Федерация, an.shtyrov@gmail.com, https://orcid.org/0000-0002-9090-7516 